Search Search Results

Free Accepted Article From Repository

Add to Marked List
Tools - Searches and alerts - Search History Marked List

8. Look Up Full Text Full Text from Publisher
Free Accepted Article From Repository

Find PDF

\section{Design and synthesis of a novel mPGES-1 lead inhibitor guided by 3D-QSAR CoMFA}

By: Aluwi, MFFM (Aluwi, Mohd Fadhlizil Fasihi Mohd) ${ }^{[1]}$; Rullah, K (Rullah, Kamal) ${ }^{[2]} ;$ Koeberle, A (Koeberle, Andreas) $^{[3]}$; Werz, O (Werz, Oliver) ${ }^{[3]}$; Razak, NSA (Razak, Nur Sakinah Abdul) ${ }^{[4]}$; Wei, LS (Wei, Leong Sze) ${ }^{[5]}$; Salim, F (Salim, Fatimah) ${ }^{[6]}$; Ismail, NH (Ismail, Nor Hadiani) ${ }^{[6]}$; Jantan, I

(Jantan, Ibrahim) $^{\left[{ }^{[7]}\right.}$; Wai, LK (Wai, Lam Kok) ${ }^{[4]}$

View Web of Science ResearcherID and ORCID

JOURNAL OF MOLECULAR STRUCTURE

Volume: 1196 Pages: $844-850$

DOI: $10.1016 /$ j. molstruc. 2019.07.004

Published: NOV 152019

Document Type: Article

View Journal Impact

\section{Abstract}

The search of novel mPGES-1 inhibitors has recently intensified probably due to the superior safety in comparison to existing anti-inflammatory drugs. Although two mPGES-1 inhibitors have entered clinical trials, none has yet reached the market. In this study, we performed modifications guided by 3DQSAR CoMFA on 2, which is an unsymmetrical curcumin derivative with low binding affinity towards MPGES-1. To counter the PAINS properties predicted for 2, the diketone linker was replaced with a pyrazole ring. On the other hand, both prenyl and carboxylate ester groups were introduced to improve the activity. When tested in vitro, 11 suppressed PGE(2) biosynthesis in activated macrophages and showed promising human mPGES-1 inhibition in microsomes of interleukin- 1 beta-stimulated A549 cells. Altogether, 11 has been identified as a potential mPGES-1 inhibitor and could be a promising lead for a novel class of mPGES-1 inhibitors. (C) 2019 Elsevier B.V. All rights reserved.

\section{Keywords}

Author Keywords: 3D-QSAR COMFA; PGE(2); mPGES-1; PAINS

KeyWords Plus: PROSTAGLANDIN E-2 BIOSYNTHESIS; DIARYLPENTANOID ANALOGS; NITRIC-OXIDE; BIOLOGICAL EVALUATION; CRYSTAL-STRUCTURE; IDENTIFICATION; SIMULATIONS; ANTIOXIDANT; DOCKING; MURINE

\section{Author Information}

Reprint Address: Aluwi, MFFM (reprint author)

+ Univ Malaysia Pahang, Fac Ind Sci \& Technol, Gambang 26300, Pahang, Malaysia.

Reprint Address: Wai, LK (reprint author)

+ Univ Kebangsaan Malaysia, Fac Pharm, Drug \& Herbal Res Ctr, Jalan Raja Muda Abdul Aziz, Kuala Lumpur 50300, Malaysia.

Addresses:

+ [1] Univ Malaysia Pahang, Fac Ind Sci \& Technol, Gambang 26300, Pahang, Malaysia

+ [2] Int Islamic Univ Malaysia, Dept Pharmaceut Chem, Kuliyyah Pharm, Kuantan 25200, Pahang, Malaysia

+ [3] Friedrich Schiller Univ Jena, Inst Pharm, Dept Pharmaceut Med Chem, D-07743 Jena, Germany

+ [4] Univ Kebangsaan Malaysia, Fac Pharm, Drug \& Herbal Res Ctr, Jalan Raja Muda Abdul Aziz, Kuala Lumpur 50300, Malaysia

+ [5] Univ Putra Malaysia, Fac Biotechnol \& Biomol Sci, Dept Microbiol, Serdang 43400, Selangor, Malaysia

+ [6] Univ Teknol MARA, Atta Ur Rahman Inst Nat Prod Discovery, Kampus Puncak Alam, Puncak Alam 42300, Selangor, Malaysia

[ 7 ] Taylor Univ, Sch Pharm, Lakeside Campus,1 Jalan Taylor, Subang Jaya 47500, Selangor Darul, Malaysia

E-mail Addresses: fasihi@ump.edu.my; david_lam@ukm.edu.my

\section{Funding}

\begin{tabular}{|c|c|}
\hline Funding Agency & Grant Number \\
\hline Ministry of Energy, Science, Technology, Environment and Climate Change (MESTECC), Malaysia & 02-01-02SF00665 \\
\hline FRGS, Ministry of High Education, Malaysia & FRGS/2/2014/ST01/UKM/02/3 \\
\hline Universiti Kebangsaan Malaysia & UKM-DIP-2014-16 \\
\hline
\end{tabular}

View funding text

Publisher

ELSEVIER, RADARWEG 29, 1043 NX AMSTERDAM, NETHERLANDS

Journal Information

Impact Factor: Journal Citation Reports

Categories / Classification

Research Areas: Chemistry

\section{Citation Network}

In Web of Science Core Collection

0

Times Cited

Create Citation Alert

\section{5}

Cited References

View Related Records

Use in Web of Science

Web of Science Usage Count

13

13

Last 180 Days $\quad$ Since 2013

Learn more

This record is from:

Web of Science Core Collection

- Science Citation Index Expanded

Suggest a correction

If you would like to improve the quality of the data in this record, please suggest a correction. 


\section{Cited References: 25}

1. Synthesis of unsymmetrical monocarbonyl curcumin analogues with potent inhibition on prostaglandin E-2 production in LPS-induced murine and human Times Cited: 25 macrophages cell lines

By: Aluwi, Mohd Fadhlizil Fasihi Mohd; Rullah, Kamal; Yamin, Bohari M.; et al.

BIOORGANIC \& MEDICINAL CHEMISTRY LETTERS Volume: 26 Issue: 10 Pages: 2531-2538 Published: MAY 152016

2. Molecular dynamics simulations of a fluid bilayer of dipalmitoylphosphatidylcholine at full hydration, constant pressure, and constant temperature

By: Berger, O; Edholm, O; Jahnig, F

BIOPHYSICAL JOURNAL Volume: 72 Issue: 5 Pages: 2002-2013 Published: MAY 1997

3. Pharmacological evaluation and docking studies of alpha,beta-unsaturated carbonyl based synthetic compounds as inhibitors of secretory phospholipase Times Cited: 35 $A(2)$, cyclooxygenases, lipoxygenase and proinflammatory cytokines

By: Bukhari, Syed Nasir Abbas; Lauro, Gianluigi; Jantan, Ibrahim; et al.

BIOORGANIC \& MEDICINAL CHEMISTRY Volume: 22 Issue: 15 Pages: 4151-4161 Published: AUG 12014

4. Coupling of COX-1 to MPGES1 for prostaglandin E-2 biosynthesis in the murine mammary gland

Times Cited: 21

By: Chandrasekharan, S; Foley, NA; Jania, L; et al.

JOURNAL OF LIPID RESEARCH Volume: 46 Issue: 12 Pages: 2636-2648 Published: DEC 2005

5. Identification and development of MPGES-1 inhibitors: where we are at?

Times Cited: 69

By: Chang, Hui-Hua; Meuillet, Emmanuelle J.

FUTURE MEDICINAL CHEMISTRY Volume: 3 Issue: 15 Pages: 1909-1934 Published: NOV 2011

6. PARTICLE MESH EWALD - AN N.LOG(N) METHOD FOR EWALD SUMS IN LARGE SYSTEMS

Times Cited: 15,026

BY: DARDEN, T; YORK, D; PEDERSEN, L

JOURNAL OF CHEMICAL PHYSICS Volume: 98 Issue: 12 Pages: 10089-10092 Published: JUN 151993

7. Synthesis, biological evaluation and QSAR studies of diarylpentanoid analogues as potential nitric oxide inhibitors

Times Cited: 16

By: Faudzi, S. M. Mohd; Leong, S. W.; Abas, F.; et al.

MEDCHEMCOMM Volume: 6 Issue: 6 Pages: 1069-1080 Published: 2015

8. LINCS: A linear constraint solver for molecular simulations

Times Cited: 7,842

By: Hess, B; Bekker, H; Berendsen, HJC; et al.

JOURNAL OF COMPUTATIONAL CHEMISTRY Volume: 18 Issue: 12 Pages: $1463-1472$ Published: SEP 1997

9. Can Small Chemical Modifications of Natural Pan-inhibitors Modulate the Biological Selectivity? The Case of Curcumin Prenylated Derivatives Acting as

Times Cited: 18 HDAC or mPGES-1 Inhibitors

By: Iranshahi, Mehrdad; Chini, Maria Giovanna; Masullo, Milena; et al.

JOURNAL OF NATURAL PRODUCTS Volume: 78 Issue: 12 Pages: 2867-2879 Published: DEC 2015

10. Structural basis for induced formation of the inflammatory mediator prostaglandin E-2

Times Cited: 114

By: Jegerschold, Caroline; Paweizik, Sven-Christian; Purhonen, Pasi; et al.

PROCEEDINGS OF THE NATIONAL ACADEMY OF SCIENCES OF THE UNITED STATES OF AMERICA Volume: 105 Issue: 32 Pages: $11110-11115$ Published: AUG 12 2008

11. Licofelone suppresses prostaglandin $\mathrm{E}(2)$ formation by interference with the inducible microsomal prostaglandin $\mathrm{E}(2)$ synthase-1

Times Cited: 11

By: Koeberle, Andreas; Siemoneit, Ulf; Buehring, Ulrike; et al.

JOURNAL OF PHARMACOLOGY AND EXPERIMENTAL THERAPEUTICS Volume: 326 Issue: 3 Pages: 975-982 Published: SEP 2008

12. Curcumin blocks prostaglandin E-2 biosynthesis through direct inhibition of the microsomal prostaglandin E-2 synthase-1

Times Cited: 73

By: Koeberle, Andreas; Northoff, Hinnak; Werz, Oliver

MOLECULAR CANCER THERAPEUTICS Volume: 8 Issue: 8 Pages: 2348-2355 Published: AUG 2009

13. Synthesis and biological evaluation of curcumin-like diarylpentanoid analogues for anti-inflammatory, antioxidant and anti-tyrosinase activities

By: Lee, Ka-Heng; Aziz, Farida Haryani Ab.; Syahida, Ahmad; et al.

EUROPEAN JOURNAL OF MEDICINAL CHEMISTRY Volume: 44 Issue: 8 Pages: 3195-3200 Published: AUG 2009

14. Nitric oxide inhibitory activity and antioxidant evaluations of 2-benzoyl-6-benzylidenecyclohexanone analogs, a novel series of curcuminoid and diarylpentanoid derivatives

By: Leong, Sze Wei; Faudzi, Siti Munirah Mohd; Abas, Faridah; et al. 
16. An Automated Force Field Topology Builder (ATB) and Repository: Version 1.0

17. A MOLECULAR-DYNAMICS METHOD FOR SIMULATIONS IN THE CANONICAL ENSEMBLE

MOLECULAR PHYSICS Volume: 52 Issue: 2 Pages: 255-268 Published: 1984

18. CRYSTAL-STRUCTURE AND PAIR POTENTIALS - A MOLECULAR-DYNAMICS STUDY

21. Inhibition of prostaglandin E-2 production by synthetic minor prenylated chalcones and flavonoids: Synthesis, biological activity, crystal structure, and in Times Cited: 23 silico evaluation

By: Rullah, Kamal; Aluwi, Mohd Fadhlizil Fasihi Mohd; Yamin, Bohari M.; et al.

BIOORGANIC \& MEDICINAL CHEMISTRY LETTERS Volume: 24 Issue: 16 Pages: 3826-3834 Published: AUG 152014

22. The effects of a synthetic curcuminoid analogue, 2,6-bis-(4-hydroxyl-3-methoxybenzylidine)cyclohexanone on proinflammatory signaling pathways and Times Cited: 21 CLP-induced lethal sepsis in mice

By: Tham, Chau Ling; Lam, Kok Wai; Rajajendram, Revathee; et al.

EUROPEAN JOURNAL OF PHARMACOLOGY Volume: 652 Issue: 1-3 Pages: 136-144 Published: FEB 102011

23. A synthetic curcuminoid derivative inhibits nitric oxide and proinflammatory cytokine synthesis

By: Van der Spoel, D; Lindahl, E; Hess, B; et al.

JOURNAL OF COMPUTATIONAL CHEMISTRY Volume: 26 Issue: 16 Pages: 1701-1718 Published: DEC 2005

25. Detailed analysis of grid-based molecular docking: A case study of CDOCKER - A CHARMm-based MD docking algorithm By: Wu, GS; Robertson, DH; Brooks, CL; et al. JOURNAL OF COMPUTATIONAL CHEMISTRY Volume: 24 Issue: 13 Pages: 1549-1562 Published: OCT 2003

Showing 25 of $25 \quad$ View All in Cited References page 